\title{
UTILIZATION OF ARTIFICIAL INTELLIGENCE IN PUBLIC RELATIONS AS A BOUNDARY SPANNING IN E-COMMERCE TYPE OF B2C
}

\author{
Marshelia Gloria Narida \\ Communication Science, Universitas Kristen Indonesia, Jakarta \\ gloriamarshelia@gmail.com
}

\begin{abstract}
Business competition in website-based online sales in the shape of e-commerce in Indonesia creates a challenge for e-commerce companies to have the right strategy to increase the customers' interest so that they will make a purchase transaction through the e-commerce. As one of e-commerce with Busines to Customer (B2C) transactions, Sale Stock (www.salestockindonesia.com) applies the role of public relations as boundary spanning as a strategy to manage corporate communications with customers. The application of this public relations role is carried out by utilizing Artificial Intelligence (AI) named Soraya as a liaison or provider of information formalized through the Information Technology (IT) channel, scanning and monitoring the organization's external environment, protecting organizations, processing information coming from outside the organization, and gathering, channeling, and selecting current data flows and then becoming information analysis. For Sale Stock, utilizing communication and information technology in the role of public relations will bring benefits in the form of ease of companies to communicate with new customers, promote products to new customers and customers. They become a hallmark of e-commerce in creating attractiveness for customers.
\end{abstract}

Keywords: Public Relations, boundary spanning, e-commerce dan Artificial Intelligence

DOI: 10.33541/sp.v19i1.1643

Sociae Polites : Majalah IImiah Sosial Politik

Faculty of Social and Political Science, Universitas Kristen Indonesia

ISSN 1410-3745 print/ ISSN 2620-4975 online

Volume 19, Number 1 (January - June 2018)

Pages 4-17 


\section{Introduction}

The presence of internet-based communication technology as a new media has been changing various aspects of community life in Indonesia, one of which is the economic aspect. Initially, the sale and purchase of goods or services take place through agreements and agreements conducted by both parties through face-to-face meetings. However, the development of the internet now, buying and selling transactions can only be done via mobile phones, gadgets, or computers that are connected to the internet so that the purchase Such meetings are no longer required. Kurnia $(2005,295)$ suggests that new media is considered both an agent of social change and an agent of change planned economy. It's in line with what was stated by Gokmen $(2012,33)$ that the development of the internet also supported by technological developments sophisticated communication in the 21 st century now has brought a revolution in the world's inevitable trade for every economic actor.

One form of communication technology used for buying and selling transactions is an electronic commerce based media website or better known as e-commerce. Laudon \& Laudon (2009: 24) define e-commerce as a process to buy and sell products electronically by consumers and from companies to a company with a computer as an intermediary for business transactions. More specifically, Dervish $(2013,211)$ suggested that e-commerce can interpret as the process of buying and selling goods or services through the World Wide Web (www) or exchange of products, services, and information through information networks such as the internet. By conducting buying and selling transactions through the internet network, sellers and buyers benefit from saving time because there is no need to face advance, the ability to reach a broad audience in a short time, and cost lower than conventional transactions. It is in line with what is Kurnia (2005, 294) stated that trade is no longer limited by space and time because new media allows large amounts of information to be spread everywhere at the same time.

In addition to these benefits, Dervish $(2013,212)$ argues, the profit of the company or seller conducting buying and selling transactions through e-commerce as follows: (1) Get new customers: E-commerce helps companies in increasing the number of right customers from domestic and foreign due to its broader reach, (2). Attract customers to keep using the product: Electronic trading can help companies increase loyalty consumers of the products they offer, (3) Enriching the quality of service: The presence of ecommerce allows companies to improve services to consumers, with more personal interactions and conveniences in providing information that consumers want, and new experiences for consumers in shopping, (4) Serve customers without space and time restrictions: Electronic commerce allows consumers to make transactions purchase without the limitations of space and time.

The development of the e-commerce business in Indonesia is very significant. BPS shows that e-commerce is one of the fast-growing internet-based businesses in Indonesia. In addition to the data above, McKinsey, in a report titled 'Unlocking Indonesia' Digital Opportunity, 'also said, the transition to the digital realm would increase economic growth to the US \$ 150 billion in 2025 . The report also stated, 73 percent of internet users in Indonesia access the internet through mobile devices. These data illustrate that e-commerce is the business that expected to have developments that will increase from year to year in Indonesia. It certainly makes the competition between e-commerce in capturing the interest of customers to shop at their e-commerce. Below is a statistical data reported by an online shopping price comparison platform with the 
address website www.iprice.com.id (iprice2018), e-commerce competition in Indonesia based on data per quarter Q3-2018 (October 2018) is as

follows:

Figure 1. Online shop competition in Indonesia

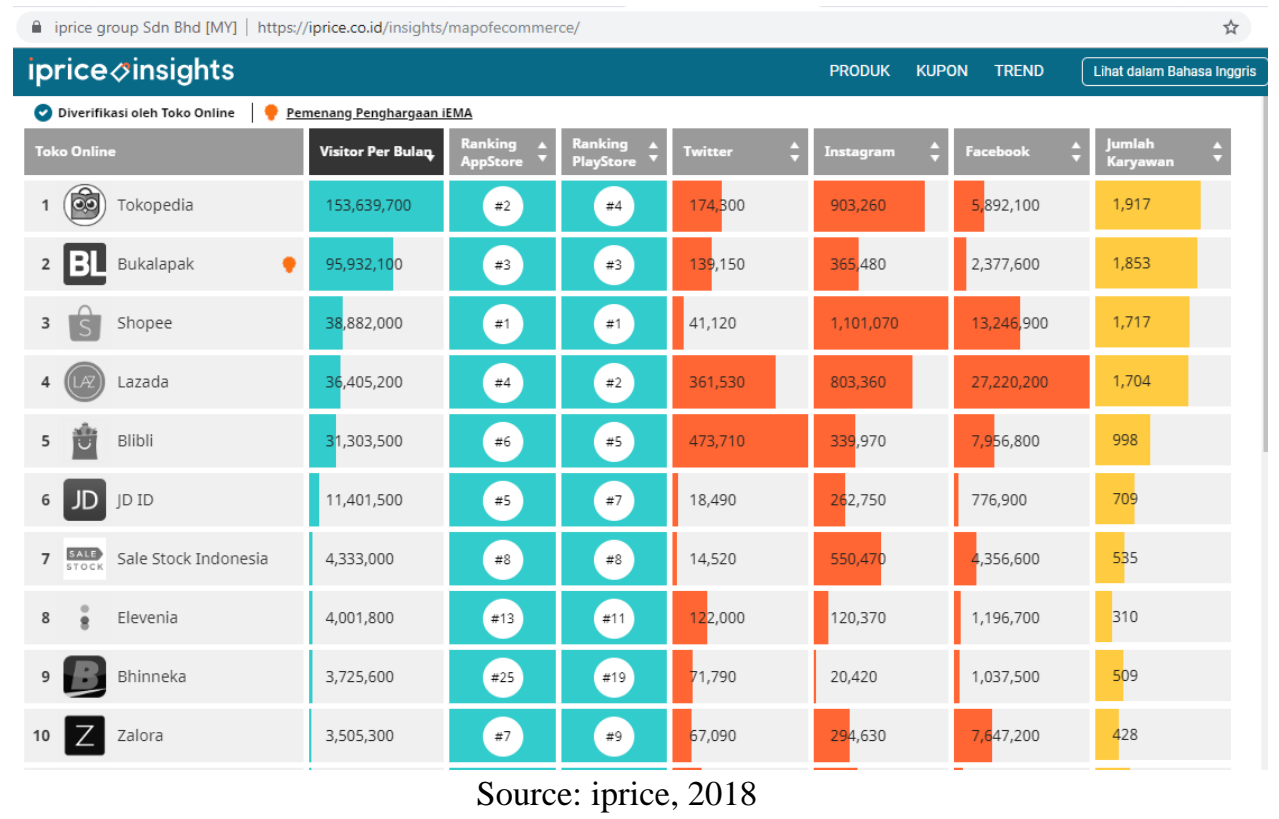

The data above measures e-commerce competition from visitors per month. Also, AppStore Ranking, PlayStore Ranking, Twitter visitors, Instagram visitors, Facebook visitors, and the number of employees who are part of the aspects of e-commerce that are will show how much e-commerce is of public interest. However, the table above is the ranking of e-commerce in Indonesia in general. And not based type transactions in ecommerce will be measured its achievements of excellence. The following is a ranking of e-commerce competition in Indonesia based on the most popular types of transactions in Indonesia, namely business to consumer and consumer to consumer. 
Figure 2. E-commerce competition in Indonesia

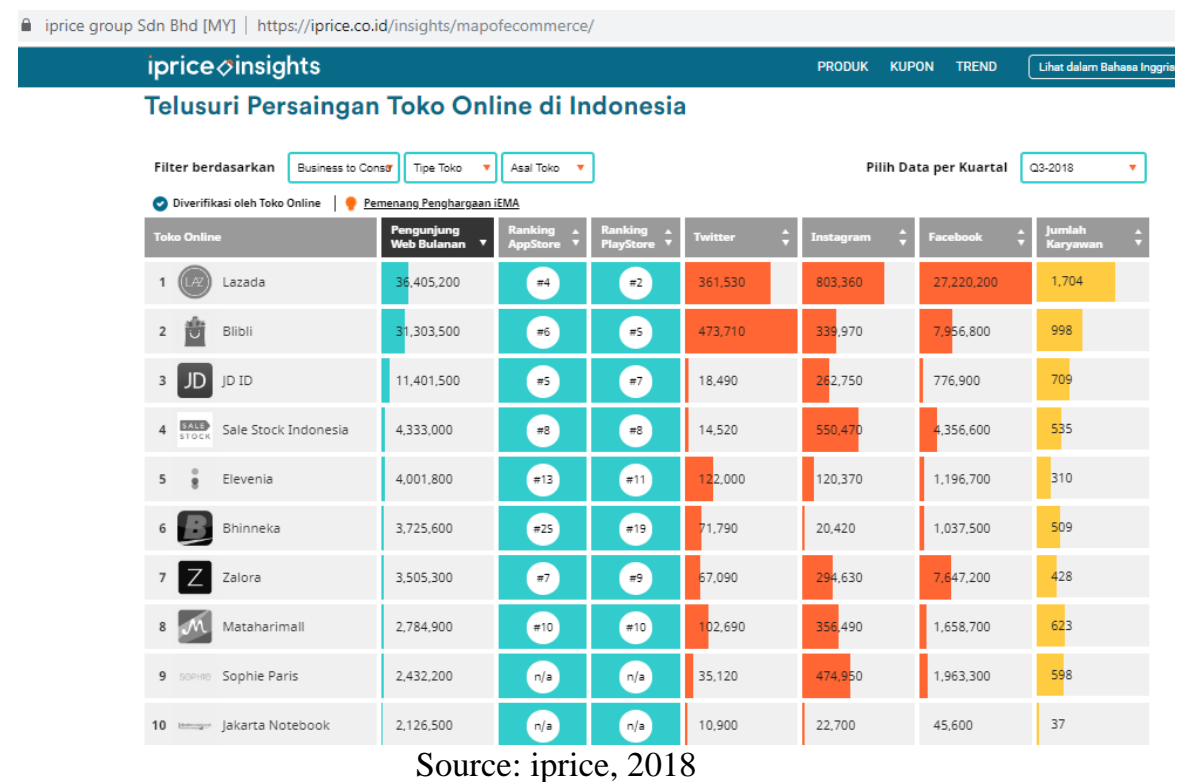

Figure 3. E-commerce competition consumer to consumer

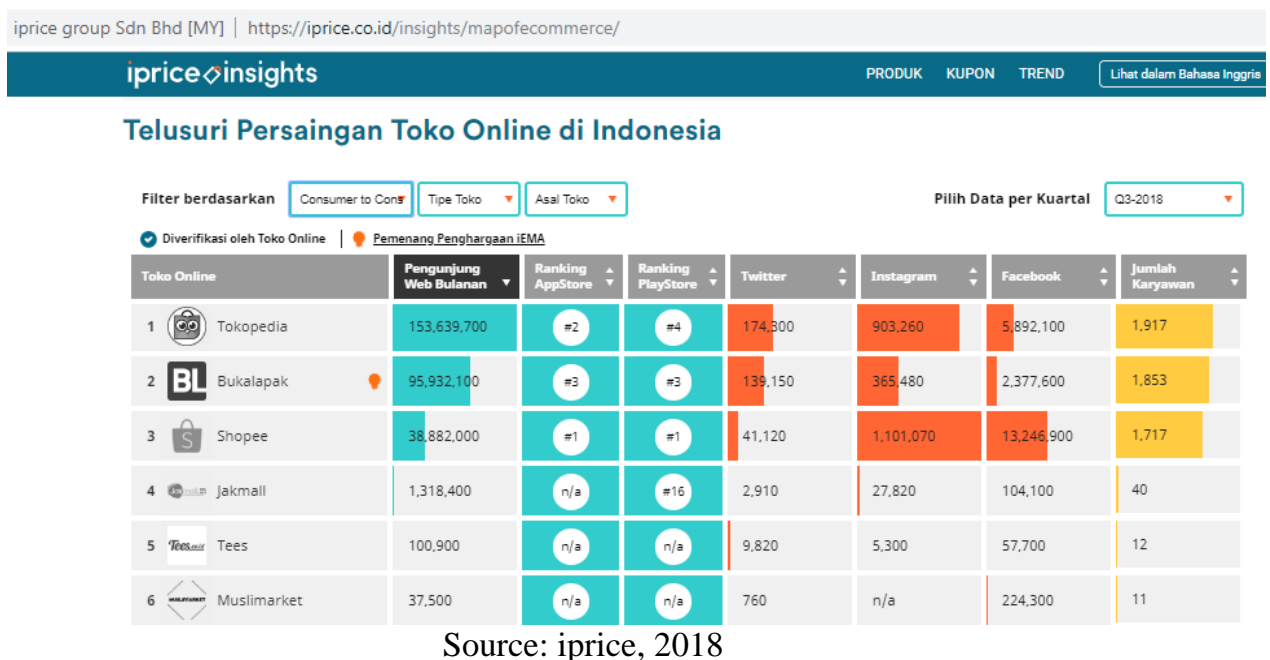

\section{Boundary Spanning}

To achieve targets and goals, every organization must have the right strategy. It is undoubtedly a consideration for every company that is no exception engaged in ecommerce in which the internet continues to grow so that the competition is even greater. One strategy that e-commerce can do is to build communication with the public by building roles public relations as boundary spanning. Grunig and Hunt in Soemirat (2010, 87) stated:

"A public relations practitioner can act based on what called limit spanning or as an acting liaison or information provider formalized through information 
technology (IT) channels with a management information system model that managed quickly, accurately, and informally. Public relations functions as a boundary spanner through managing information about problems in the external or internal environment of the organization by collecting, distributing, and selecting current information. Appropriate analysis of the top leaders of the organization as decision-makers to be the basis of the process. It was also making a strategic decision for the benefit of the organization. Even the public effectively and well-targeted in the future."

What was said by Grunig and Hunt in the paragraph above illustrates that boundary spanning is a function and role of the inside of the company whose job is to establish corporate communication with the public to gather information through communication and information technology channels for the benefit of the organization in the future. Seitel in Ruslan $(2010,309)$ defines the notion of public relations as a liaison manager (boundary manager), which is a liaison manager in an organization/management between the organization and its public, both external and internal or in other words, one foot is inside and feet others are outside the organization. Ruslan (2010, 308-309) also explains the function of public relations as boundary spanning in an organization as follows:

\begin{abstract}
"Management needs more accurate and precise information before making policy or decision. Continuously prioritized and up-to-date information needs that are usually prepared by the boundary spanner (provider or liaison, the intermediary). Boundary spanner expected to have the ability to interact with the internal and external environment of the organization. It can realize by referring to public relations practitioners who can hamper the interests of top management in decision making. It also expected to have the ability to access the information or channel aspirations and the wishes of the public."
\end{abstract}

According to Miles (quoted in Yudarwati, 2011, 113-114), there is another managerial role, the boundary spanner. This role involves several activities, including representing the organization to the public. Also, Scanning and monitoring the organization's external environment, protecting the organization, processing information that comes from outside or from the internal organization, as a gatekeeper related to information flow, conducting transactions with external parties, and conducting coordinate and regulate organizational relations with the public. In this role, public relations practitioners are involved in the process of issues management, which includes the process of identifying, monitoring, and analyzing opinions and public interests that can develop into organizational policies.

From the views and conclusions above, it can conclude that boundary spanning is the role of public relations in a company by being a liaison or information provider related to the company's external and internal environment. And that can be done by using information technology (IT) channels by collecting, distributing, and selecting current information flow then becomes an analysis of information which later submitted to the leadership of the organization as a basis for consideration of the company to make a decision. At the same time, other functions in the role of public relations as boundary spanning are collectors and processors of information and company representation to the external public. Besides, Public practice relations must not only be able to present the 
goals and philosophy of the company. It also must be able to interpret the wishes or expectations of the public externally to the company and be able to get closer to the dominant public, such as managers and parties who have the power to determine organizational goals and corporate mission.

\section{Artificial Intelligence}

In the era of development of Communication and Information Technology at this time, humans create a work of technology that used to help social work. One of them is computer-based technology called artificial intelligence (AI), which understood as the ability of a computer to think like humans (Bostrom 2014, 26). AI technology can search, process, and analyze information from various sources. The development of AI technology increasingly has a significant role, especially with the emergence of big data (Peixoto 2016, 532). Big data is a collection of vast and complex amounts of data on the internet that can search for data, process, and analyze information that can seek. John McCarthy first coined AI in 1956 at the Dartmouth Conference.

Joost N Kok stated it in his book titled Artificial Intelligence to formulate four definitions of AI, namely: (a) AI is a study in the field of computer science related to the development of computer intelligence that simulated like a rational way of thinking. In this case, AI can think like humans like learning (reasoning), reasoning (argument), and self-correction (self-correction). (b) AI is a concept where machine capabilities can improve, such as human intelligence ranging from learning (learning), adapting (adapting), self-correction (self-correction), and so forth. (c) AI is defined as "the extension of human intelligence through the use of computers, as in times past physical power was extended through the use of mechanical tools." (d) AI is also simply defined as a study conducted to improve the effectiveness of computer work through programming techniques $(2009,1)$.

From what Kok said in the paragraph above, it can conclude that AI is a result of computer technology that resembles a robot that designed to resemble the ability of humans to learn, have reason and adapt. How come? Classifying the definition of AI into four categories, namely: (1) systems that think like humans, (2) methods that act like humans, (3) systems that reason, (4) methods that work rationally $(2009,1)$. The definition gives an idea that $\mathrm{AI}$ is a computer technology that has four categories, namely having systems that can think like humans, systems that can provide reactions like humans, systems that can reason, and a system that can react intelligently.

In line with what Kok said, Chris Smith, in his book The History of Artificial Intelligence, explained, "AI ranges from machines truly capable of thinking search algorithms used to play board games. It has applications in nearly every way we use computers in society $(2006,4)$. Smith argues that AI is a machine application that can think to look for algorithms in a board game. This application resembles the way we use computers in society. Based on the ability of AI to think and analyze data, AI can utilize in activities in the management of an organization, especially public relations activities in managing the communication relationship of an organization with its public. In an organization that is engaged in the e-commerce business, AI can be used to help the task of public relations in communicating through providing information and analyzing customers as a basis for consideration or company policy. Of course, the information conveyed, as well as the accounts or systems that will be released by this company, is the 
company's strategy in competing in e-world commerce.

\section{Problems}

In the e-commerce business, the right strategy needed to achieve the company's goals and objectives. This is considering that e-commerce has its uniqueness compared to other online buying and selling media in terms of sources income. If in other internetbased online trading transactions, revenue is obtained from the sale of goods or services, that is not the case with e-commerce businesses. The primary source of income or ecommerce profit is precisely not from the sale of products or services made by the customer but from other aspects of the business of the company depending on the type of business transaction that each e-commerce has. The intense competition in the ecommerce business in Indonesia requires companies to have the right strategy in obtaining consumer appeal. Generally, e-commerce is a new commercial strategy that leads to improving the quality of products and services and improvements at the service level while providing organizational, supplier, and consumer requirements to reduce costs (Shaw 2012, 34).

Based on this opinion, it obtained that generally, e-commerce is a strategy that leads to improving the quality of the organization's products and services to parties external to reduce costs to be incurred by the company. Establish communication relationships with customers not only to know who is the company's audience but to be able to understand what the company must do in developing aspects of its business. Also, the communication made with the customer can aim to find out what the customer likes and what the customer expects the company can become the basis for consideration when trying to market a product or service. Communication with this audience can then be used as a reference when e-commerce is about to issue good policies related to company management, advertising, and discounts given to customers. Competition in e-commerce certainly requires companies not only to have them. The strategy is in the form of a step in the way of work implementation. Contained within the company internal (company management), but the plan in the direction of the use of assistive media will make the company have different performance and attractiveness from other e-commerce. It was indeed inseparable from the conditions of e-commerce business competition. Which businesses based on communication and information technology using the internet are developing all the time, thus demanding that companies also apply technology to one of the strategies in growing their business.

\section{Discussion}

Sale Stock Indonesia (Sale Stock) is an e-commerce website www.salestockindonesia.com which was established in 2014 with a type of business to Customer (B2C) transaction that sells goods of its design and production by gathering various SMEs in Indonesia. By selling their products, sale stock claims to be able to do "savings" that used to allocate to consumers and company development. It follows what said Lingga Madu, CEO of Sale Stock Indonesia: "From inventory, Sale Stock only sells its goods. We can cut inefficiency, then allocate most of the savings to consumers and the rest to build the foundation so the company can be more prominent. "(daily social 2018).

With the courage to provide the "Try First New Pay" service (CDBB), the customers who choose the COD (Cash On Delivery) payment method can try clothes that 
have ordered for 15 minutes. And after the courier arrives at the shipping location before making payment transactions, the user can return the product at that time if they don't like it and only pay for the product they desire. Through this service, Sale Stock seeks to convince customers that the products sold are "real picture" (the condition and shape of the goods according to the display of photos of the goods on the website). Also, it has detailed size and material classification according to what listed on the site so that customers who initially hesitate to shop online for fear of the goods do not match the photos, do not match the size listed on the website. No need to wait to buy at Sale Stock."

The goal is to encourage new users who previously had doubts about shopping for clothes on the online site for fear of being inappropriate when the order arrived. We decided to make CDBB a permanent service, not a periodic one that only exists periodically. We have already calculated for the CDBB service when returns occur. But from this study, we did internal research by asking respondents. The result is that as many as $74 \%$ of them mentioned the first time shopping online through Sale Stock. This makes us optimistic. "Even though Sale Stock is a moving business and uses technology as the basis for its business, Sale Stock still uses communication as a strategy to reach customers. It is done by Sale Stock, given the Competition in the e-commerce business, especially the type of $\mathrm{B} 2 \mathrm{C}$ transactions that require having the right strategy to be an attraction for customers to shop at Sale Stock. One of the strategies used by Sale Stock to achieve the company's goals and objectives is by implementing boundary spanning in the role of public relations.

In carrying out its role as Boundary Spanning, Public Relations Sale Stock utilizes Artificial Intelligence (AI) technology. This technology is named "Soraya," which can serve customers who visit the Sale Stock website for 24 hours. Through this technology, Public Relations Sale Stock greets new customers as well as deliver for customers who make the first time spending on Sale Stock. Information conveyed through "Soraya" aims to provide information to detect customers who have never shopped at Sale Stock. It looked in the example image below

Figure 4. Information to new customers

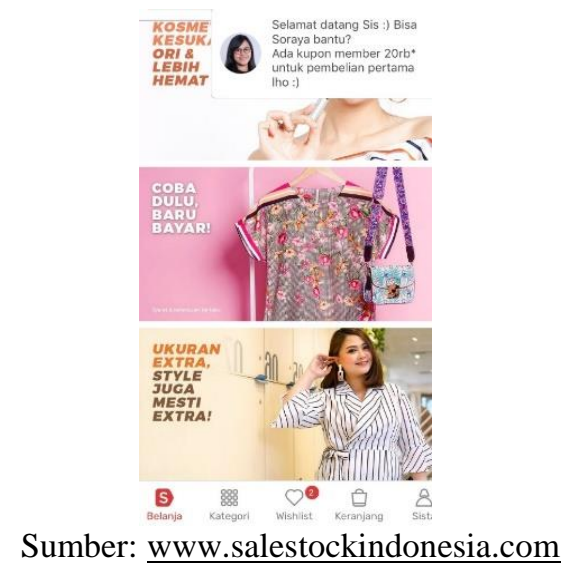

In the picture above, Soraya greets and, at the same time, asks new customers, "Welcome Sis :) Can Soraya help? There is a 20rb member coupon * for the first purchase :) ". It shows the role of boundary spanning that is carried out by Public Relations Sale Stock by becoming a liaison or information provider formalized through the Information 
Technology (IT) channel. In this case, a technology called "Soraya," which used to detect new customers who first visit the Website Sale Stock or have never done a transaction. The role of public relations as the next boundary spanning by using an AI called "Soraya" is to provide services by prioritizing customers to find the fashion category they like quickly. Through technology services, this communication, Public Relations Sale Stock Indonesia, carries out its function as boundary spanning by providing information that distributed through information technology (IT). How it works from AI, in this case, is to detect collecting data in the form of what categories are sought by customer's every time they open the Sale Stock website.

Soraya can identify what kind of clothing categories are often opened by customers, so from this detection, Sale Stock can directly promote the division of detection results by displaying the type of interest of the customer each time the customer opens the Sale Stock website. It's already as an effort to Sale Stock in providing services to customers. As well as assessment materials for what categories are the most much in demand by customer's every time they access the Sale Stock website, so the company gets input on products such as what products will be improved.

Figure 5. Service by e-commerce

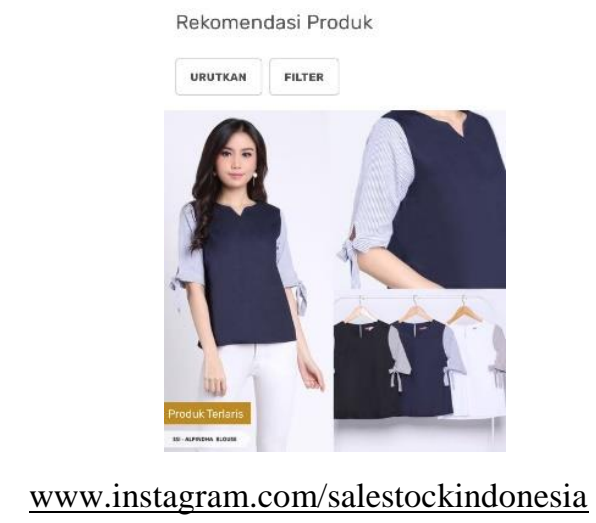

In addition to providing information by using "Soraya," public relations also carries out its role of being the company's liaison with customers through WhatsApp to provide information regarding the status of payment and delivery of goods from Sale Stock Indonesia to the customer. This WhatsApp connected to "Soraya" automatically, so that when a customer makes an order through the website, the customer will receive an official WhatsApp from Sale Stock regarding the status of the shipment of goods. Customer WhatsApp numbers obtained from customer personal data listed on the website.

Figure 6. Communication with customers using WhatsApp 


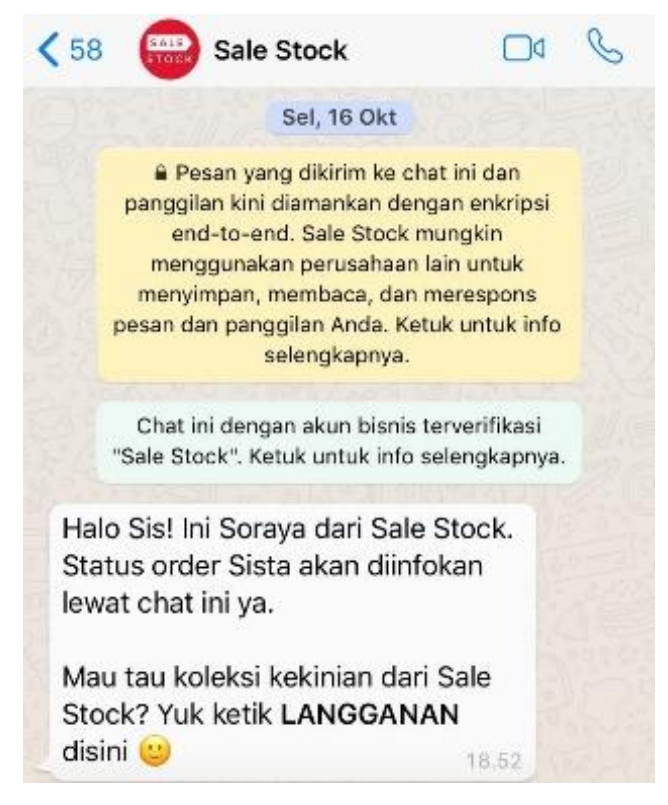

In the picture above, Soraya sends a message via WhatsApp with the sentence, "Hello Sis! I'm Soraya from Sale Stock". Sist, order status will inform via this chat. Do you want to know the current collection of Sell Stock? Come on type LANGGANAN here ". The message via WhatsApp shows that Soraya conveys information to the customer who has done the transaction through the Sale Stock website that the status of the shipment of goods that have ordered will send via the WhatsApp. Besides, Soraya also informed that customers could get information about the latest Sale Stock collection through WhatsApp just by typing the word COSTUMER and sending it to Sale Stock via the WhatsApp.

Sale Stock performs its role as boundary spanning by Scanning and monitoring the organization's external environment, protecting the organization, processing information coming in from outside the organization, one of which is by scanning customer complaints using AI. Through AI technology, Sale Stock can find claims submitted by customers through social media. After getting the charge written by the customer, Sale Stock then responds by answering directly through the comments column on social media. The response conveyed by the Public Stock Sale Stock carried to protect the Sale Stock from negative assumptions that could develop through the media social due to complaints from customers. It can undoubtedly harm the Sale Stock if the customer feels the claim not responded to.

The figure below shows the role of public relations to manage information about problems in the external environment, that is, information from customers in the form of complaints about services and products of Sale Stock. Gather information from customers and providing feedback in the way of answers to claims submitted by customers shows that Public Relations Sale Stock has performed its role as boundary spanning by collecting customer complaints and managing information by giving answers directly to customers: 
Figure 7. scanning dan monitoring

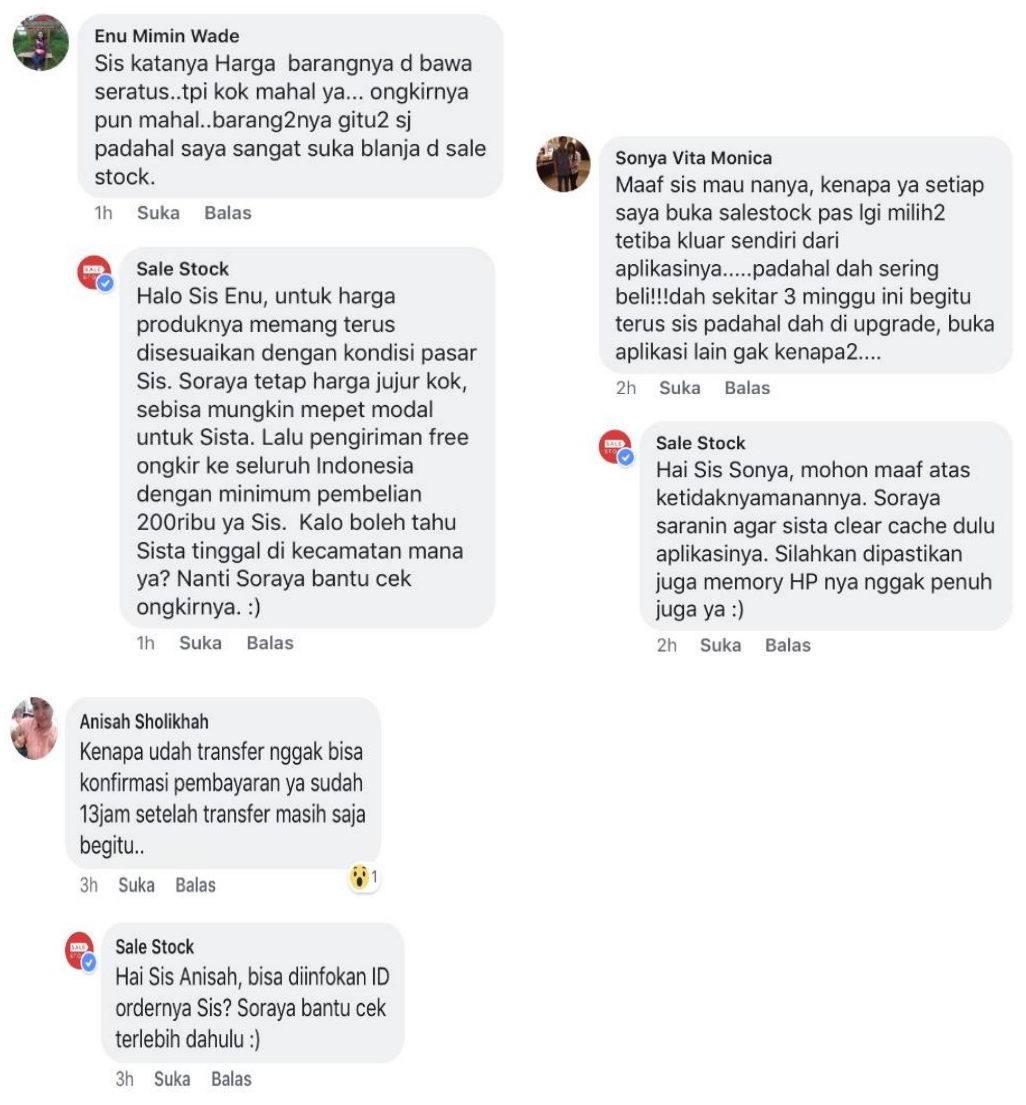

Source: www.instagram.com/salestockindonesia

In the picture above, there are three examples of complaints submitted by customers through Instagram social media. If you don't use Soraya, Sale Stock will have difficulty finding claims because this complaint is in the comments column of photos posted by Sale Stock via social media Instagram, given that comments in the form of complaints may be unreadable due to a large number of comments coming in and the variety of comments that made delivered by the customer. Through the help of Soraya, Sale Stock can find comments in the form of complaints and immediately respond to each of these comments.

In addition to Scanning and monitoring the organization's external environment, protecting the organization, processing information that comes in from outside the organization, Sale Stock also collects, distributes, and selects the latest information flow then becomes analysis information. One example is done by asking questions to customers through social media and then making the answers obtained by the customer as a material consideration for company policies related to the price and production of goods. In the picture below, Public Relations Sale Stock asks questions about customer interest in women's dresses through Facebook social media by asking questions about what customers like, whether they prefer plain dresses or dresses motive. In the posting via the Instagram account below, Sale Stock makes the question, "For matters of dress, does Sista prefer plain or motives? Write in the comments field Sista \#TeamDressPolos or \#TeamDressMotif ". Customers can write their answers through comments listed on the Instagram menu. Public relations then forward comments obtained through this 
question to the analysis section products to considered for designing products that will sell Sale Stock, especially products related to women's dresses.

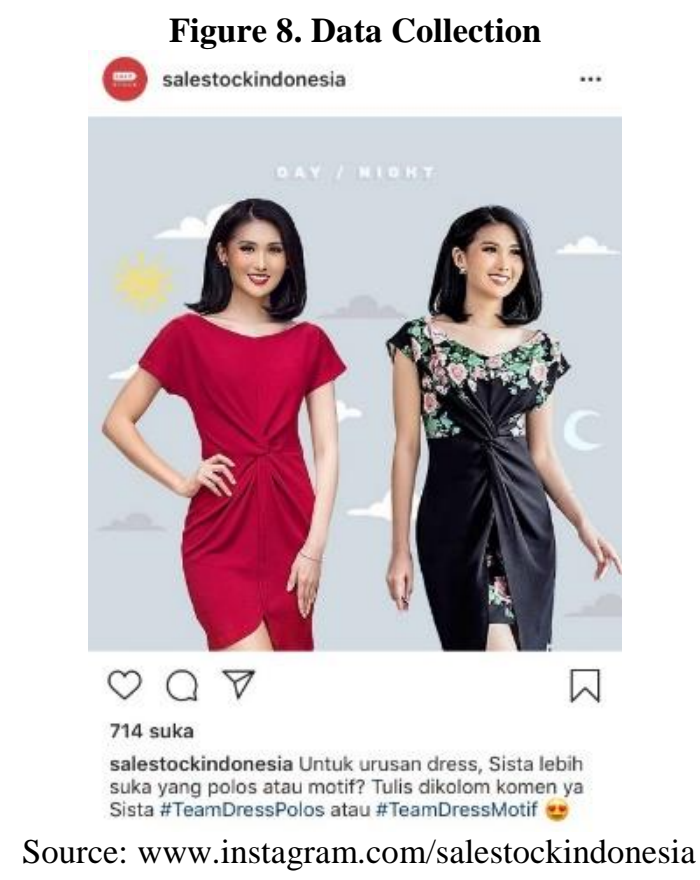

\section{Conclusion}

In the face of competing in the e-commerce business, especially with B2C (Business to Customer) transactions, Sale Stock implements strategies, one of which is by applying the Role of Public Relations as a Boundary Spanning. By using the help of Artificial Intelligence (AI) computer technology called Soraya. By using AI, Public Relations can play a role as boundary-spanning with the liaison or information provider formalized through the Information Technology (IT) channel. Also, Scanning and monitoring the organization's external environment, protecting the organization, processing information coming in from outside the organization, and gathering, distributing, and selecting the latest information flow then becomes information analysis. The use of AI by public relations in carrying out its role as boundary-spanning shows that public relations can currently utilize the development of communication. And Also, information technology to simplify and accelerate his work is specifically related to building corporate communication relationships with customers. For e-commerce, utilizing interface and information technology in the role of public relations will bring benefits in the form of ease of the company to communicate with new customers, promote products to new customers and customers. They have transacted and are characteristic of e-commerce in creating attraction for customers. 


\section{BIBLIOGRAPHY}

\section{Books}

Laudon, K., dan Laudon, J. 2009. Management Information Systems: International Edition, 11/E. Pearson Higher Education.

Shaw, M., Blanning, R., Strader, T., \& Whinston, A. (Eds.). 2012. Handbook on electronic commerce. Springer Science \& Business Media

Soemirat, S., Ardianto, E. 2010. Dasar-dasar Public Relations. Bandung: PT Remaja Rosdakarya Offset

Ruslan, R. 2010. Manajemen Public Relations dan Media Komunikasi: Konsepsi dan Aplikasi. Edisi Revisi Kesepuluh. Jakarta: PT. RajaGrafindo Persada, Rajawali Pers.

Yudarwati, Arum.2011. Public Relations dan CSR. Yogyakarta: Aspikom

Nick Bostrom. 2014. Superintelligence: Paths, Dangers, Strategies. New York: Oxford University

Joost N. Kok. 2009. Artificial Intelligence. London: Eolss Publishers

Chris Smith. 2006. The History of Artificial Intelligence. Washington: University of Washington

\section{Journal}

Kurnia, Novi. 2005. "Perkembangan Teknologi Komunikasi dan Media Baru : Implikasi terhadap Teori Komunikasi”, MediaTor, Vol. 6, No. 2, hlm. 295.

Gokmen, Aytac. 2012. "Virtual Business Operations, E-Commerce \& Its Significance and The Case of Turkey: Current Situation and Its Potential," Electron Commer Res, 12: 31-51.

Darwis, Yuliandre. 2013. "The Urgency of Communication Meda (E-commerce) in Indonesia's Creative Industry as an Effort to Increase International Business Competition: A Case Study of The Fashion Industry," The International Journal of Organizational Innovation, Vol. 5, No. 3.

Rafael Peixoto, Christophe Cruz, \& Nuno Silva, "Adaptive Learning Process for the Evolution of OntologyDescribed Classification Model in Big Data Context," Makalah disajikan Dalam SAI Computing Conference 2016, IEEE Explore, London 13-15 Juli 2016, hlm. 532

\section{Website / Social Media}

Nabila, Marsha. "Tiga Tahun Berdiri, Sale Stock Segera Capai Titik Impas dan Dulang Laba.", diakses 9 November, 2018. https://dailysocial.id/post/tiga-tahun-berdirisale-stock-segera-capai-titik-impas-dan-dulang-laba 
Sufyan, Muhammad. "Pertumbuhan e-Commerce Indonesia Tertinggi di Dunia.", diakses 9 November, 2018. https://www.liputan6.com/tekno/read/2957050/pertumbuhane-commerce-indonesia-tertinggi-di-dunia

Iprice. 2017. "Peta E-commerce Indonesia." Telusuri Persaingan Toko Online di $\begin{array}{lllll}\text { Indonesia. } & \text { diakses } & 7 & \text { November } & 2018 .\end{array}$

https://iprice.co.id/insights/mapofecommerce/

www.salestockindonesia.com

www.instagram.com/salestockindonesia 